\title{
THE INSIGHT INTO THE ISSUE OF ADDICTION IN THE PROCESS OF SOCIAL WORK AMONG ROMA FAMILIES OF SINTI
}

\section{Eva Klimentová}

\begin{abstract}
Sinti belong to the quantitatively small groups of Roma people in the Czech Republic and they are different in many ways from other Roma people. Their culture is characteristic in terms of the emphasis on the autonomy towards the major society. In the same time, they respect the society and its laws, they want to be integrated, not to stand out. Sinti encourage their children to study, they are proud to be hard working and independent from the social benefit system, they are proud that they do not have any conflict with the majority. It is specific for this group to react strictly in the situation when the clan traditions and principles are broken and one of the worst is to become drug addict.

This article describes clan rules of Sinti, which regulates the usage of drugs within the community. The goal of this article is to describe one case of a particular Roma clan, in which the tribal principles and rules influence also social work in its preventive and curative form when its solving the issues of drug addiction. The emphasis here is also on the reflection of the clan rules in the possibilities of the social work process with a drug addicted client and his/her family.
\end{abstract}

\section{Keywords}

Roma people, Sinti, clan traditions, drug addiction, social work

\section{Historical introduction}

Although it is very complicated to define social work target group on the basis of the ethnicity, we can say, that Roma people definitely belong among important target groups of the social work in the Czech Republic. This does not mean, that every Roma person should be considered as potential social work client. We define the social work client as a person (family, group, community) who fails to solve his/her social problems by him or herself or with the support of his or her close social environment (alike Havrdová, 1999; 
Navrátil, 2001; Matoušek, 2003). This definition would be valid for the majority of the Czech Roma population. The reasons for this lay mainly in the history.

Over the centuries the Roma people have been the nation without homeland, a minority in various societies and cultures, wanderers without homes, in diaspora. The Roma people in the whole Europe have common historical experience of persecution, discrimination, marginalization, oppression, social exclusion (Hübschmannová, 1998; Horváthová, 2002). The Roma people have been too different from the majority, because of their language, culture, ethnicity, life style.

Possibly the Roma people have been wandering to Europe since the twelve century from India via The Small Asia and Balkan. They have worked in the field of crafts to keep themselves alive. They worked as blacksmiths, they used to make kettles, also they offered music and juggler production, herbalism. The Roma people were future tellers, they cured animals and they were also horse handlers (Daniel, 1994; Říčan, 1998; Stewart, 2005). Their different life style (wandering, clothes, magic etc.) was seen as suspicious among the settled people. These fears were strengthened by the experience when Roma people used to steal goods, cheated during the horse trade and stole crops from the fields in times when their offer of services had no request (Daniel, 1994). It is understandable that the residents who were also poor and had poor sources reacted unfriendly. (Fraser, 1998)

The persecution of the Roma people was more or less permanent in the area of nowadays Czech Republic during the whole middle age (for more details see Horváthová, 2002). There were also issues in co-habiting of the Roma people with the others during the new age. In the years 1928 and 1929 took place the first process of summation of "gipsies" and there were almost forty thousands of Roma people older than fourteen years, who received "gipsy legitimation". This was the way to register and label not only the wandering people, but also other Roma people on the ethnical basis. Through this Roma people were more social excluded and stigmatized then before. (Horváthová, 2002)

The "gipsy legitimations" later helped in the process of concentrating Roma people in the time of the protectorate and in so called "final solution". Roma holocaust (Roma people call it Porajmos) was the end for approximately thirty-five thousands of Roma people from Bohemia and Moravia; overall it was not survived by two hundred thousands of Roma people (Rose, 2009). After the second world war only individual Roma people returned to Bohemia and Moravia and there they joined those Roma people who avoided the deportation thanks to their definition of being indispensable working force. It is possible that this extreme experience of holocaust was the reason to assimilate with the majority (Horváthová, 2002). Shortly after the war the approximate number of Roma people in the area of nowadays Czech Republic was in hundreds, somewhere between 600 and 1,000 people. (Nečas \& Miklušáková, 2012)

Soon after the war there were hundreds of Roma people coming to Bohemia and Moravia from Slovakia. These were people who survived the war rampage in the Slovak state with significantly smaller damage. In Bohemia and Moravia, they were looking for better working opportunities and higher quality of life (Hübschmannová, 1998). The first migration was spontaneous, the next were organized and supported by the state, which 
was looking for people working for the renovation of the displaced border areas. This way there were created places with high concentration of Roma people for example in Ostrava, Kladno, or Sudety (Haišman, 1989; Říčan, 1998). This process of insensitive settling of Roma people from various sub-ethnic and clan groups next to each other had negative impact on the harmony of Roma communities. Their natural sources of social control disappeared as well as their traditions, culture (Lacková, 2010). On the other hand, the totalitarian regime brought to Roma people the security of employment, dignified housing, undiscriminating social and health care. There were also many advantage in material and social sources for "the citizens of Roma origin". This protective approach mostly paralyzed the Roma people, their problems were not solved, only covered by the backdrop which was liked by the majority. (Barša, 1999; Říčan, 1998)

All together these and many more negative influences led the Roma people into the deep social disintegration from the year 1950. By the disintegration in this context we mean the process of decomposition of the structural and functional unity of social group. For the members of the disintegrated groups it means the threat of social exclusion. This leads to exclusion from social network, barriers on the way to institutions and services, disappearance of the bonds between the majority and the social excluded group, restriction in horizontal and vertical social and spatial mobility. In the same time social disintegration and social exclusion deepens the polarization of the society, the social excluded get separated from the social values and norms, their social participation is weakened. (Navrátil, 2003; Duffy in Mareš, Horáková, \& Rákoszyová, 2008; Topinka, 2013) The fall of the totalitarian regime in 1989 seemed to be a promise for the better future not only in terms of Roma issues, but Říčan (1998) emphasizes the negative consequences of the democratization of the society. In connection with the Roma people issues it is mainly unemployment connected with discrimination on the labour market and also easily reachable attractive but harmful substances. It is not only about drugs, but also about credits, loans and consumption. In the new social circumstances based on individual performance the Roma people have not been able to react flexible enough and many of them have fallen into deep social exclusion. This has been even deepened by traditionally negative attitude of the major Czech society toward the Roma ethnic. Červenka (2015) says, that in the representative research of the Centre for public opinion research $36 \%$ of the respondents described the cohabitation with Roma people as very bad, and $47 \%$ as rather bad.

\section{Current situation}

Roma people count to be the biggest minority in the Czech Republic. The experts estimate, that in 2014 there were approximately 250,000-300,000 Roma people living in the Czech Republic. This is approximately $2.3 \%$ from the whole population. These expert estimations came from the professionals who worked with the Roma community, and the definition of a Roma was a person who considers to be Roma him or herself and in the same time he or she does not declare the ethnicity all the time (e.g. in the census), 
and/or he or she is considered to be a Roma by a significant part of his or her social environment. (Zpráva o stavu romské menšiny v České Republice za rok 2014, 2014) As it was mentioned above, the Czech majority considers the Roma minority as problematic with lack of motivation to contribute to social prosperity. This attitude is supported by some facts, for example (if we do not specify other way, Zpráva o stavu romské menšiny v České republice za rok 2014, 2014):

- the proportion of Roma pupils among all the pupils who are educated according to the document "Education programme frame for elementary schools and pupils with light education difficulties (mental retardation)" - it means education in special schools - is $32.4 \%$. This number means, that the Roma pupils have 14 times higher proportion in these schools that is the proportion of the whole population of Roma people in the Czech Republic;

- in 2014 there were 80-85\% unemployed people from the socially excluded regions, in which the Roma people make the majority. Many of the Roma resigned on the participation in the official labour market. They live on financial social benefits, some of them have illegal jobs, or other alternative ways to have some income (similarly Konopásek, 1998);

- according to the expert estimation, there are between 30 and $60 \%$ of Roma children living in the institutions. Because of their ethnicity, it is almost impossible to find families to foster these socially orphaned kids;

- the average life expectancy of Roma people is approximately ten years less than of the majority, infant and children mortality is twice bigger than the national average;

- among Roma people there are far more underage mothers and significantly lower birth weight of a new-born;

- $65 \%$ of adult Roma men smoke regularly, as well as $57 \%$ of adult Roma women, which is significantly more than in the whole Czech population, in which we see between 28 and 32 percent of adult smokers (Sovinová, Csémy, \& Kernová, 2014). Roma women smoke also when they are pregnant, children begin to smoke in early childhood and if not, they face passive smoking. Lately there is an increase of illegal drugs users. Roma people abuse alcohol the same way like the majority;

- the data about Roma criminality are not collected. Nowadays we estimate, that the proportion of Roma offenders among the prosecuted persons is approximately eight or ten percent, which means, that the Roma criminality is three times or four times higher than in majority (Šišková, 2001; Romové v České republice: 19451998, 1999).

Despite what laic population usually think, Roma people are a significantly heterogeneous ethnic group. Individual subethnic groups of Roma people (clans) differ from one another in many important aspects, e.g. the rules of community cohabitation, preferred values, culture, the relation towards majority. It is not possible to describe the Roma people as homogenous group with specific way of life. (Fraser, 1998; Hübschmannová, 1998; Jakoubek \& Budilová, 2009)

The biggest group among the Czech Roma people is the group of the Slovakian Roma people, whose ancestors came from Slovakia after the second world war or later. Slovakian 
Roma people are 75-85\% of all Roma people in the Czech Republic. Approximately $10 \%$ belong to the Olasky Roma people, who tend to isolate themselves from other Roma people and from the majority. The rest of the Roma people $10-15 \%$ are Roma people originally from Hungary. There are hundreds of the Czech Roma people, descendants of those who lived here before 1939 and survived the horror of the second world war; and the German Sinti (Sinty, Sinto). (Davidová, 1997; Pavelčíková, 2004; Hlaváček, 2014)

\section{Sinti}

It is necessary for social work with Roma people to respect the Roma culture, traditions and habits. For that, social worker needs to have knowledge of the different values, life experience, relation to the majority, and culture in its broadest sense. It was mentioned above, that Roma people are not a homogenous group, various sub-ethnic groups differ in many aspects which can have some influence on social work and its results.

This article focuses on the topic of Sinti, not a large group of Roma people living in the Czech Republic. The origin of the word Sinti is not clear. Sinti (Sinto, Cinto) belong to the group of German Roma people. In Germany there are far more Sinti than in the Czech Republic. Sinti use their own language which include many German words and phrases and it also based on French and English. It is not Romany language or its dialect. The language of Sinti is hidden from the majority, no expert description of it exists. (Rombase, 2003; Cohn, 2009)

Kašparová (2014) explains, that Sinti consider themselves to be so different from the other Roma people that the tribal names have to stand side by side - "Sinti and Roma". Sinti are mostly very well assimilated (and not only in Germany), they have higher life standard than the other Roma people who migrated for longer time after the second world war looking for their own place within the majority. "The different names Sinti and Roma do not refer only to the difference of origin. To be a Sinti means higher social status and the acceptance from the majority ..." (Kašparová, 2014, p. 30-31)

In the Czech Republic region, the Sinti community until the $50^{\text {th }}$ of the $20^{\text {th }}$ century was concentrated in the border part of the country. There were only a few Sinti who were not killed in concentration camps or other ways during the second world war and they returned to Bohemia and Moravia, the rest settled in the democratic part of Germany. Nowadays the Czech Sinti live mainly in bigger towns and they keep in touch with their families in Germany and other countries. (Fraser, 1998)

\section{The information sources, methods of research}

Sinti try to hide their culture, language and rules of the clan from the expert and laic public. That is why it is extremely difficult to gain such information (alike Horváthová, 2002). In following text, we present knowledge which comes from two mutually related sources. The first one is long-term social work process with one particular family of 
the Czech Sinti. The main person in the family is Anna1, a woman in her middle age. When the social work started in the family, Anna was 25 years old. Anna accepted two children from her broad family to raise them (her mother's brother's children, so she is their cousin). The children were terribly neglected by their biological mother, who ethnically belonged to the majority, their mother's brother sexually abused both children. The father of the children was imprisoned those days and the children Robert and Veronika were approximately four and three years old. Anna was looking after both children for many years without any institutional assistance, the representatives of the institutions did not know about that matter. Anna did not receive any financial or other social support; her care was unconditioned but without any formal auspices. I was a social worker who started working with the family in the moment when the biological parents began to re-claim the children back to their care after the father return from prison. Anna submitted a custody proposal, so she could foster the children officially. The social work with the family was rather intense, lasted for a year and was finished by the agreement with Anna's successful custody. Social work with the family continued in the form of support for the foster family in cases and situations when the demands of the institutions were bigger then Anna could have managed. I keep in touch with the family for more than twenty years, Veronika and Robert are already adult and they have their own families and they are doing really well. At the moment Anna fosters another Roma boy, he is in school age. During the cooperation with the family, there used to come up the need to react to specific information about the clan habits which Anna present very cautiously and rarely. Anna slightly opened for me the doors which lead to the hidden world of ancestral traditions, which influence everyday life of the clan members. There were many interesting issues which I did not ask about, because I did not need the information for the anamnesis and because of the social work ethics I did not want to be to curious.

The second source of information presented here in terms of the issue of addiction in Sinti families is a research, which was supported by Open Society Fund and Norway Grants. The research was based on the qualitative research strategies and it took one year of longer or shorter interviews with Anna in years 2015 and 2016. Anna agreed with the goal of the research was specified as to undercover the traditions and culture of Sinti so it could be useful for the social workers and other helping professionals. The outcome of the research is a narrative biography Anna (Klimentová, 2016). The methodology of this article is based on the outcomes of this long-term observation and many narrative interviews.

The impact of the data is limited by the fact, that the only source of information here is Anna herself. The picture of Sinti tradition gained from her was not possible to compare with other sources of information or other communication partners from the Sinti community. When the members of the community were asked for the interview, they have always refused so far.

\footnotetext{
1 The names and other main data, which could be used to identify the individuals, who participated in the research, were changed.
} 


\section{Sinti and drugs}

Sinti are very strict in respecting the values and norms of the majority and they are active in their effort to fulfil them. They are proud of their ability to live independent life based on working and avoiding social benefits; the ability to gain property legally and managing the property is highly valuated, they refuse loans and usury, they support children in education and they are anxious about cleaning.

Their community is significantly hierarchized and based on patriarchy principles. The head of the clan is nowadays a man in his middle age and living in Germany, to this man all other members of the clan are responsible. This man receives extraordinary respect. The same receive the members of the council, which has legislative and judicial power and consists of the older respected members of the clan. This council makes decisions about serious sanctions against the clan members. Among the major misdemeanours, which are punished by the council belong the violence against children and drug addiction. The most serious punishment from the council is the expel from the clan, which is going to be described further in more details.

In this point it is necessary to clarify the term "the purity of the clan". Pure Sinti is that person, who has mother and father of pure Sinti blood. Those Sinti are of only a little number, in the Czech Republic there are probably only individual numbers. Many Sinti marry or live in partnerships with Roma people from other clan groups or the majority. Their children do not have pure blood but they are allowed to decide to became members of the clan, when they grow up, and when they are capable to fulfil the rules of the clan and follow the strict clan traditions. People like this must be accepted by the clan. Many Sinti are convinced, that "mixing blood" brings social pathology to the community and threatens the unity of the clan. This also about a great dilemma - it is not only disengagement, but also the tightening of the rules of keeping the clan blood pure, which brings potential risks to the community in its viability and the community can vanish.

The Sinti attitude towards psychoactive substances (drugs) is mostly negative. They distinguish two categories of these substances, which could be named as legal and illegal.

Legal drugs like alcohol and tobacco are tolerated. When an individual uses such drugs, the assessment of the community depends on the gender of the user. When a man is smoking and drinking alcohol, it is tolerated. When it comes to women, it is assumed that they avoid these substances. Anna remembered her father: "My daddy, he was a smoker, and he used to go smoking outside, because of us, the children, and he always said: my daughter, you must never ever light up a cigarette, you must never smoke, you'd rather have a good chunk of meat ...". When Anna was raising her son (she named her foster kids daughter and son, but they used to call her "Anička", the youngest boy nowadays calls her "aunt"), she used to tell him, when he was a teenager, "... if you ever want to have a beer or so, it is not a problem, you are the man, so it is alright, but you must always return to your family and not to be too familiar with alcohol". 
When the family gets together, it usually means that there are tens of related people coming from the whole Europe; the men are offered with alcohol, but the inebriety is not expected. If this situation comes forward, the drunk man is a target of derision and he is observed to be seen if it was only a single accident or if the addiction is developing. Women do not drink alcohol at all, or only in a symbolic way, for example a little glass of sweet liqueur. "It is not decent for a woman to drink." When a person drinks hard and the alcohol addiction develops, the situation is seen as a great failure and in the same shameful way as other illegal drug addictions; even more when the drinking person could not fulfil the expectations connected with the social roles.

The Sinti's attitude towards illegal drugs is very distinctive, they are strictly forbidden. The community reacts strongly and decisively towards all forms of interaction between a person and a drug. The prevention of drug addiction is in the centre of Santi's attention from very early childhood, because drugs are seen to be seriously dangerous for individuals, families and the community as such. "There are really small children, let us say around seven, who must be clearly explained in a good will, and nice words. Father must be absolutely strict; it is not only about some "no-no-no" (Anna is very expressive in her gestures). And mother has to say that the drugs are wrong, in the ways they damage people. And then to show them what it can do with people, for example when they go mad. Or other examples alike. It is necessary to explain to the kids all the time." Each family spends a lot of time raising their children properly and they "make them study, and not to become criminals, or drug users, alcoholics". The mean of control is precisely and fixedly structured free time schedule which takes place under the control of parents and other relatives. Even when Anna's kids were in their teenage age and adolescence, they had to come back home from the outside at least at half past seven. They had a lot of activities out of home, but mostly under some adult supervision, for example in a kid's club or a sport club; or accompanied by a member of the family. "It is stronger in our family, when the cousins come together and are also friends; then it is why nothing wrong can happen." Anna used to fear the danger of drugs, she used to fear some youth groups and was afraid of their kids joining them. She used to be afraid that Veronika could have got pregnant. Anna remembers: "... every mum, and I know this, loves her children and keeps them off drugs as far as possible. The same way as me in case of Veronika and Rob, when I used to tell them and begged on my knees, to let them know, that I would have had killed me, that it would have had destroyed me, if they would have done it. That is painful ...". Looking after children is a process accompanied with a lot of preventive measures, using deterrent examples. Anna welcomed all preventive activities from school in the topic of drugs and drug addiction. When the children told her about those activities, she supported all the arguments with her own ones and mainly with her emotionally coloured positive attitude. "I was always grateful, when they were told about that at school. You know, that I was right and that it really is wrong and bad, and that it cannot turn right and what threatens them. They then had it at home as well as at school, well."

If that may happen that a child is caught in the act of experimenting with narcotics, the family do as much as they can to help the child out of the danger of an addiction. In the 
community it is acceptable "a little accident", but long term abuse of drugs is a something to receive the strongest punishment which is disqualification off the community. This possible sanction is something that makes families act and put as much effort as possible to help the child avoid this unwanted behaviour. One of the tools for solving such problem is asking some other member of the family or community from a different town to look after the child for a while. They choose a place so the old social bonds can be broken including those with drugs, so the child is led off the bad environment. This process is usually absolutely non-formal, in case of under-age children without any cooperation with social institutions.

As it was mentioned above, to be expelled from the community is the strongest punishment and it comes to a person after usually two the most serious lapses. The first one is when they hurt children and the second is drug addiction. Excommunication can be temporary or permanent. In case of drugs, the expulsion is permanent, "...drugs, it is something to be punished with life-sentence ...". Excommunications means, that the community breaks all contacts. The expelled person cannot come back, cannot count him or herself as Sinti anymore, cannot share house with the family, cannot share table, cannot be buried in a family tomb. It is absolute social isolation, which is also emphasized by the fact, that the individual has limited opportunities to join other social groups. Being Sinti in origin, the person is refused by other Romany people, who are also seen by this person (thanks to the lifelong "snob" education) to be unclean (prasto). The person is also refused by the majority, because of generally negative attitude towards Roma. Drug addiction stigma only strengthens this exclusion.

Anna explains the essence of the excommunication: "the person must not be buried in the family tomb ...he/she cannot sit with me by my table ...l shall not give him or her food or a drink." In everyday life it is not strictly forbidden to have a formal contact with the expelled, which is even more painful for the one: "they would not criticize the person without saying 'hallo, they would have a chat, or so. But the form is to say, good morning, how are you and good bye. That is that. He/she cannot step under my roof ever, that is simply not possible anymore." When it comes to the social work process, this situation is a great complication, because it is almost impossible to motivate the person to give up on drugs, when he or she has no peace to return and has no promise for a better future. He or she is not Sinti anymore, other Romany are considered to be "unclean", majority does not accept him or her. In the same time the social worker cannot count with the family to be supportive for the person to avoid drugs. This form of social support is taken away from the addict as such.

In the family described here, we speak about this serious punishment in one case - the case of the father of the children, who Anna took care of. Despite they were in a very close family relationship, the decision of the council about expelling the father from the community was not questioned and was followed very strictly. In case of meeting him, Anna briefly informed him about the children, but he could not get any closer to them. Surprisingly the father after many years of using methamphetamines healed and fully avoided drugs in the time when the children just became self-lawful. He took detox and community therapy afterwards, also he took long outpatient aftercare. After all this 
the father came to Anna to thank her for "having the kind in proper education, in respect and honour". He gave to Anna great presents, Anna talked repeatedly about a huge bouquet. He apologized to the children. In spite of all this, the clan did not forgive him, even when the close family spoke up for him. The sanctions in the community function as means of general prevention, they should be seen as strong deterrent for the others. "There is no way back ... It is forever, unfortunately ... you have put some dirt on the family and ... you cannot let such person into your flat, cannot meet him/her ... the person does not exist for you anymore, he/she is without a family and stay this way forever ... the family is not able to forgive, because of the rules, any when they say to do it, we do it ... You become a black sheep of the family beware ... otherwise the family get revenge."

The father of the children remained sober in spite of all complications and problems until the last day of his life. His precocious death was caused by late somatic complications of addiction. According to Anna, his family begged for his sake and the clan finally accepted him to be buried in the family tomb. The funeral was classic Sinti with all traditional requisites, which also means, that a lot of relatives from abroad came over. They also paid for the expensive funeral and layout of the tomb. Anna tells this story with tears in her eyes, she says, that this is unbelievably beautiful happy end, to which she contributed. According to Anna, the issue of addictions is still an actual topic in the community and it is seen as one of the most serious. Nowadays the community discuss the option to expel parents of an addicted child. This is something Anna do not agree with. "I agree with that completely, that this is not good, I tend to talk to the person, who suggests that, to show that there are ways, these days we have new age and it is not working. I know, that he or she wants to help, but when in the puberty a child takes something (drug) then the mother is not to be blamed. So you cannot blame the father or the mother, that would mean for fifteen or twenty years and it is not possible this way." She also pronounces the argument about bigger families, where it is more likely to bring the children up in better way and for example "one of them slips ... it is not about the genetics, it is about the system, which ...you let the kids out and they become friends with somebody and to become part of the group, they take it ... Because this can happen to anyone, I can have a grandchild or - God help - and it is not my fault, how can I prevent that, when simply the child goes outside with a group, you do not know anything and then you realize later."

In the interview it was clear, that this topic was difficult for Anna. On one hand, she is conforming with clan rules and laws and she is proud of them; on the other hand, she considers herself to be a mother who can make as much effort as she can, any her children can be threatened by drugs anyway. She answers the question, how she would solve the issue of one of her children slipping towards drug use: "... the eyes cannot tell, and anyone breaks the rules sometimes, so you understand ... you must always help your child first and then fight..." But the possibility of sanctions makes her panicking. "I do not know about that, this is even impossible to imagine, such horror. You know, this is terrifying ...". 


\section{Conclusion}

To know the cultures of social work clients is the necessary basis for the efficient social work process. So called Romany issue is focused in the Czech social work from its early days, which we date to the raise of democratic Czechoslovakia in 1918. Despite many social policy measures, despite intense research effort and social work in the field, the integration of Romany into majority is not that successful, so we could name our cohabitation to be non-collision.

One of the causes of this unwanted situation may be the fact, that social workers see the Roma people to be value and culture homogenous group. This text points at one particular example of an individual Roma clan. This example shows how the traditions and habits influence social work process in its preventive and curative form when solving the problems of drug addiction.

Social work is a profession and one of its characteristics is the necessity of solving various and difficult ethical problems and dilemmas. In the example above, there is no stress in terms of the procedure of preventing drug addiction. In this matter, the values of Sinti and the majority are consistent and social worker can offer efficient support for the families to prevent their children from drugs. This help is not only accepted by the families, but also developed in an innovative way. Completely different is the situation, when the clan expelled a member for his or her drug addiction. To overcome the addiction, it is necessary to be motivated, which must be really strong, for drug addiction is a serious disease and the addict must by continuously supported not to fall into relapse. The Sinti community is not supportive for its members this way, because it would be in a conflict with their moral standard. Social worker walks on a thin ice of moral relativism. On one hand there is the moral standard of his/her profession which says, that he/she has to help. Social worker considers his/her moral duty to help the addict and motivate him/her to therapy and the professional standards leads him/her to make the family of the addict to cooperate effectively. On the other hand, there are culture values of Sinti, which are highly valuated and supportive for their clan cohesion. These values say, that it is forbidden to help the addict. The status of the community towards the addict is not against the law and it is manifestation of individual culture, social worker should be able to respect that.

There is an inevitable question of the responsibility for change of the social worker in such situations. How big is the appropriate space for the community to fulfil its right for selfdetermination (Zastrow, 1992), and how big must be the space for the addict and his/her self-determination, when he/she is expelled from the community. How we can define the space for fulfilling the personal values of social worker, professional values of social work and value of majority. In such cases, when there is a conflict of interests, values, cultures, we can see the need of individualization social worker procedure and individual steps must be continuously reflected in the discourse. Veselský (2013) suggests this discussion to be broad, multidisciplinary and in the cooperation with supervisors in the activities of professional organizations. 


\section{References}

Barša, P. (1999). Politická teorie multikulturalismu [Political theory of multiculturalism]. Brno: Centrum pro studium demokracie a kultury (CDK).

Cohn, W. (2009). Cikáni [Gypsies]. Praha: Sociologické nakladatelství (SLON).

Červenka, J. (2015). Romové a soužití s nimi očima české veřejnosti - duben 2015 [Roma and coexistence with them through the eyes of the Czech public - April 2015]. Praha: Sociologický ústav AV ČR. Retrieved from http://cvvm.soc.cas.cz/media/com_ form2content/documents/c1/a7388/f3/ov150602.pdf

Daniel, B. (1994). Dějiny Romů [History of Roma]. Olomouc: Univerzita Palackého.

Davidová, E. (1997). K současným změnám romského společenství, jeho postavení a způsobu života [The current changes in the Roma community, its status and way of life]. Pedagogická orientace, 7(2), 63-70.

Fraser, A. (1998). Cikáni [Gypsies]. Praha: Nakladatelství Lidové noviny.

Haišman, T. (1989). Cikáni-Romové v Československu v posledních 43 letech: Hledali jen oni sami sebe? [Gypsies-Roma in Czechoslovakia in the last 43 years: Were they the only ones looking for themselves?]. Český lid, 76(1), 33-39.

Havrdová, Z. (1999). Kompetence v praxi sociální práce [Competences in the social work practice]. Praha: Osmium.

Hlaváček, K. (2014). Romové v České republice [Roma in the Czech Republic]. Praha: Parlamentní institut. Retrieved from http://www.psp.cz/doc/00/09/17/00091753.pdf

Horváthová, J. (2002). Kapitoly z dějin Romů [Chapters from the history of Roma]. Praha: Člověk v tísni.

Hübschmannová, M. (1998). Šaj pes dovakeras = Můžeme se domluvit [Šaj pes dovakeras = We can arrange]. Olomouc: Univerzita Palackého.

Jakoubek, M., \& Budilová, L. (Eds.). (2009). Cikánské skupiny a jejich sociální organizace [Gypsy groups and their social organisations]. Brno: Centrum pro studium demokracie a kultury (CDK).

Kašparová, I. (2014). Politika romství - romská politika [Politics of romaism - Roma politics]. Praha: Sociologické nakladatelství (SLON). 
Klimentová, E. (2016). Anna. Olomouc: Univerzita Palackého v Olomouci.

Konopásek, Z. (1998). Estetika sociálního státu: o krizi reprezentace (nejen) sociálního zabezpečeni [Aesthetics of the welfare state: about the crisis of representation (not only) of social security]. Praha: G plus G.

Lacková, E. (2010). Narodila jsem se pod štastnou hvězdou [I was born under a lucky star]. Praha: Triáda.

Mareš, P., Horáková, M., \& Rákoczyová, M. (2008). Sociální exkluze na lokální úrovni [Social exclusion at local level]. Praha: Výzkumný ústav práce a sociálních věcí. Retrieved from http://praha.vupsv.cz/Fulltext/vz_280.pdf

Matoušek, O. (2003). Slovník sociální práce [Dictionary of Social Work]. Praha: Portál.

Navrátil, P. (2001). Teorie a metody sociální práce [Theory and Methods of Social Work]. Brno: Marek Zeman.

Navrátil, P. (2003). Integrace (Romů) v kontextu životních situací: konceptualizace [Integration (of Gypsies) in the context of their living situations: conceptualization]. In Sborník prací Fakulty sociálních studií Brněnské univerzity Sociální studia 10. Retrieved from http://socstudia.fss.muni.cz/dokumenty/080305104534.pdf

Nečas, C., \& Miklušáková, M. (2012). Historie Romů na území České republiky [History of Roma on the territory of the Czech Republic]. Praha: Český rozhlas. Retrieved from http:// romove.radio.cz/cz/clanek/18785

Nešpor, K. (2000). Návykové chování a závislost [Addictive behavior and addiction]. Praha: Portál.

Pavelčíková, N. (2004). Romové v českých zemích v letech 1945-1989 [Roma in the czech lands in 1945-1989]. Praha: Úřad dokumentace a vyšetřování zločinu komunismu PČR.

Rombase. (2003). Romové - subetnické skupiny [Roma - sub-ethnic groups]. Praha: Rombase. Retrieved from http://rombase.uni-graz.at/cgi-bin/art.cgi?src=data/ethn/ topics/names.cs.xml

Romové v České republice: 1945-1998 [Roma in the Czech Republic: 1945-1998]. (1999). Praha: Socioklub.

Rose, R. (Ed.). (2009). Nacistická genocida Sintů a Romů: katalog ke stálé výstavě ve Státním muzeu v Osvětimi [Nazi genocide of the Sinti and Roma: catalogue for the permanent exhibition at the State Museum in Auschwitz]. Praha: Romano džaniben. 
Říčan, P. (Ed.). (1998). S Romy žít budeme - jde o to jak: dějiny, současná situace, kořeny problémů, naděje společné budoucnosti [We will live with the Roma - it is about how: history, the current situation, the roots of problems, the hope of a common future]. Praha: Portál.

Sovinová, H., Csémy, L., \& Kernová, V. (2014). Uživání tabáku a alkoholu v České republice: Zpráva o situaci za období posledních deseti let [Tobacco and alcohol use in the Czech Republic: Report on the situation over the last ten years]. Praha: SZÚ. Retrieved from http://www.szu.cz/uploads/documents/czzp/zavislosti/TabakAlko2004_2013.pdf

Stewart, M. (2005). Čas Cikánů [Gypsies Time]. Brno: Barrister \& Principal.

Šišková, T. (2001). Menšiny a migranti v České republice [Minorities and migrants in the Czech Republic]. Praha: Portál.

Topinka, D. (2013). Lifestyles in the Socially Excluded Areas of Moravian Cities and Towns. In H. Kubátová (Ed.), Ways of Life in the Late Modernity (pp. 321-342). Olomouc: Univerzita Palackého v Olomouci.

Veselský, P. (2013). Filozofie a etika pro sociální pracovníky [Philosophy and ethics for social workers]. Olomouc: Univerzita Palackého v Olomouci.

Zastrow, Ch. (1992). The Practice of Social Work. Belmont: Wadsworth Pub. Co.

Zpráva o stavu romské menšiny v České republice za rok 2014 [Report on the state of the Roma minority in the Czech Republic for 2014]. (2014). Praha: Úrad vlády ČR. Retrieved from http://www.vlada.cz/assets/ppov/zalezitosti-romske-komunity/dokumenty/Zpravao-stavu-romske-mensiny-2014.pdf

\section{Author}

PhDr. Eva Klimentová, Ph.D.

Faculty of Arts, Palacký University Olomouc

The Department of Sociology, Andragogy and Cultural Anthropology

Kř́žkovského 512/10, 77900 Olomouc, Czech Republic

eva.klimentova@upol.cz 